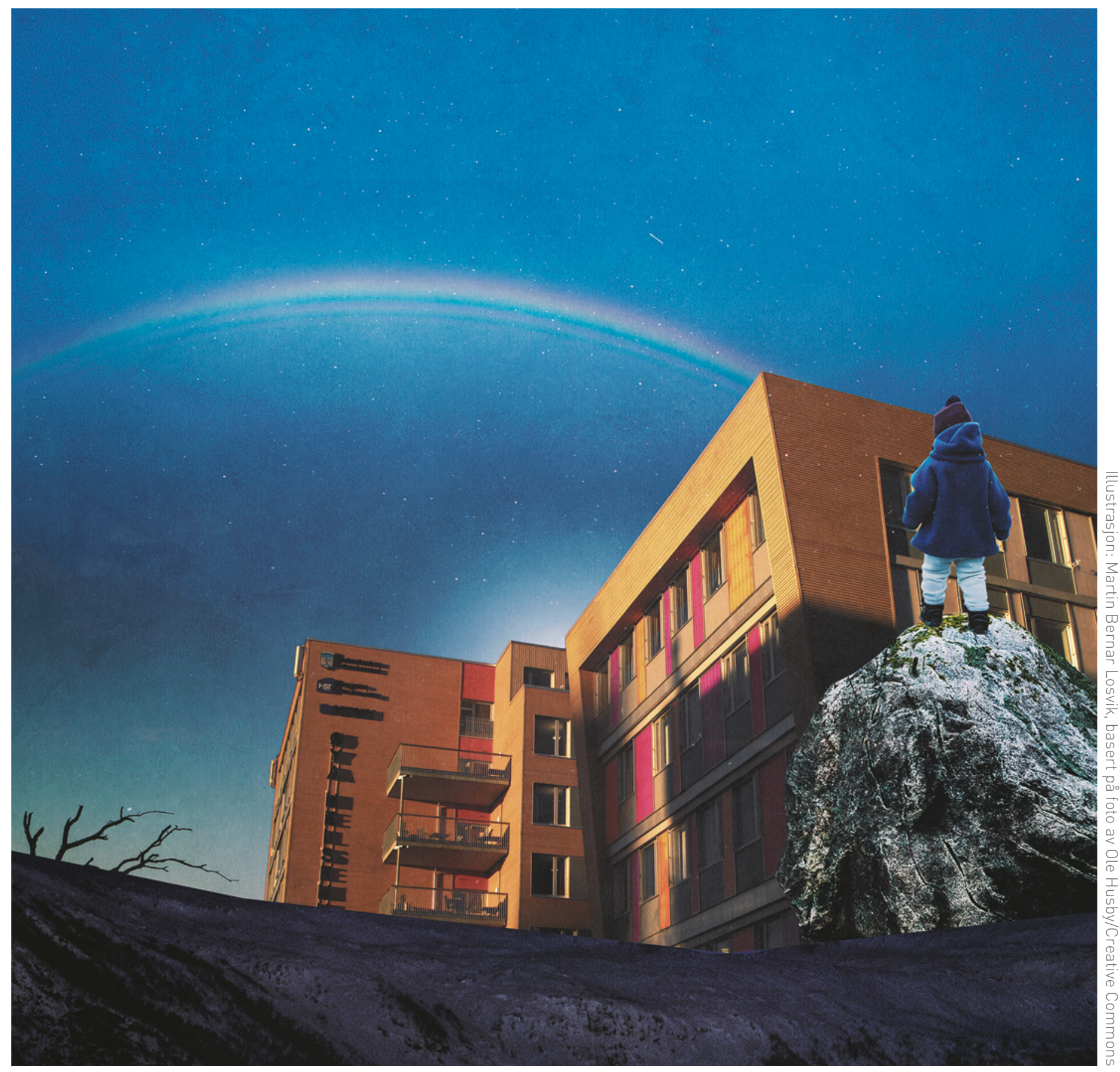

\title{
Øya helsehus
}

Helsehuset ligger i Trondheim ved Norges teknisk-naturvitenskapelige universitet. Dette er ett av fire
helsehus i kommunen. Her er det avdeling for rehabilitering og lindrende behandling og en kommunal akutt døgnenhet. I tillegg er den kommunale kreftkoordinatoren, Høgskolen i Sør-Trøndelags avdeling for sykepleie, Edda legesenter og Senter for samfunnsmedisin ved Norges teknisk-naturvitenskapelige universitet lokalisert i huset. 